\title{
PENGARUH PEMANFAATAN ALAT PERAGA IPS TERHADAP KINERJA GURU SEKOLAH DASAR
}

\author{
Suttrisno \\ suttrisno06@gmail.com \\ Universitas Trunojoyo Madura
}

\begin{abstract}
ABSTRAK
Penelitian ini bertujuan untuk mengetahui pengaruh Pemanfaatan alat peraga IPS terhadap kinerja guru Sekolah Dasar. Jenis penelitian ini adalah penelitian kuantitatif non eksperimen dengan metode penelitian kuantitatif deskriptif. Sampel penelitian ini sebanyak 30 guru di 10 Sekolah Dasar di Kecamatan Pragaan Kabupaten Sumenep melalui teknik pengambilan sampel Nonprobability Sampling dengan sampel jenuh. Pengumpulan data menggunakan beberapa instrumen yaitu angket dan lembar observasi Pemanfaatan alat peraga IPS dan angket kinerja guru. Analisis data menggunakan Uji regresi linier sederhana dan Uji-t untuk melihat seberapa besar pengaruh variabel bebas terhadap variabel terikat. Hasil penelitian menunjukkan bahwa hasil uji regresi linier sederhana dan uji signifikasi diperoleh data persamaan regresi linier sederhana kontribusi yang disumbangkan variabel X terhadap variabel $Y$ sebesar $Y=23,23+0,505 X$ dengan nilai $r=0,526$. Hasil analisis menggunakan uji signifikan thitung $(3,271)>t_{\text {tabel }}(2,048)$ maka Ho ditolak, dengan demikian artinya terdapat pengaruh signifikan antara Pemanfaatan alat peraga IPS terhadap kinerja guru.
\end{abstract}

Kata kunci: pemanfaatan alat peraga, IPS, kinerja guru, sekolah dasar

\section{THE INFLUENCE OF TEACHING AIDS UTILIZATION OF SOCIAL SCIENCE SUBJECT TOWARDS TEACHER'S PERFORMANCE}

\begin{abstract}
This research aim is to know the influence of teaching aids utilization of social science subject (variable X) towards teacher's performance (variable Y). This study uses quantitative noneksperiment by applying research quantitative descriptive reserch. The sample of the reserch is 30 teachers of 10 elementary school in Pragaan Sumenep by using questionnaire and observation sheet of the availability properties and teacher performance questionnaire with a saturated sample. Data analysis using simple linear regression test and $t$ test to see the how big effect of independent variables on the dependent variable. The result of this study using simple linier regression test and significance test obtained data of simple linear regression equation, the contribution of the variable $X$ to $Y$ is $Y=23,23+0,505 X$ with $r=0,526$. The result of significance test shows that $t_{\text {count }}(3,271)>t_{\text {table }}(2,048)$, then $H_{o}$ is rejected. From the result of the analysis, it can be seen that teaching aids utilization of Social Science subjet is incluences tecaher's performance.
\end{abstract}

Keywords: Teaching aids utilization of Social science subject, Teacher's Performance, Elementary School 


\section{PENDAHULUAN}

Bagi manusia pendidikan termasuk kebutuhan penting yang perannya sangat banyak sehingga tidak bisa dijauhkan satu sama yang lain. Pendidikan bisa dijadikan alat dalam meningkatkan dan memaksimalkan kualitas sumber daya manusianya di suatu bangsa. Mutu pendidikan nasional telah diatur dalam Standar nasional pendidikan dengan tujuan menjamin kecerdasan bangsa dan membentuk watak serta peradaban bangsa yang bermartabat. Untuk menggapai cita-cita luhur itu, idealnya ada delapan hal yang harus terpenuhi dalam pelaksanaan pendidikan. Kedelapan impian ideal tersebut meliputi : standart intisari, standart pelaksanaan, standart kualitas output, dan standart tendik yang semuanya diatur dalam "Peraturan Pemerintah (PP) No.19 Tahun 2005 tentang Standart Nasional Pendidikan".

Melihat begitu pentingnya pendidikan maka kualitas dan mutu pendidikan harus terus dimaksimalkan. Menurut Mulyasa (2010) kualitas sumber daya manusia (SDA) rendah dapat menghambat pembangunan dan perkembangan ekonomi nasional dan menjadi masalah mengakar. Salah satu cara dalam memaksimalkan mutu pendidikan yang ada yakni dengan meningkatkan kinerja pendidik. Pendidik/guru adalah ujung tombak yang memiliki peran penting dalam meningkatkan kualitas siswa. Agar mencapai hasil yang optimal, selain menjalankan tugas sesuai tupoksi guru ia juga harus membimbing dan mengarahkan cara dan gaya belajar siswa. Kualitas lulusan siswa sangat dipengaruhi oleh kinerja mereka. Jika kualitas lulusan tersebut rendah pada akhirnya berpengaruh juga terhadap capaian tujuan pendidikan. Kinerja guru dapat menignkat apabila mereka memahami cara kerja yang ikhlas dan menjalankan tugasnya dengan baik sesuai harapan bangsa.

Mulyasa (2010) juga menambahkan banyak cara untuk meningkatkan kinerja guru khususnya dalam pembelajaran. Misalnya dilakukan melalui mengikuti diklat, seminar ataupun pelatihan. Seperti diklat, seminar ataupun pelatihan-pelatihan misalnya metode pembelajaran, pembuatan media/alat peraga, pemilahan/pengembangan $\mathrm{SK} / \mathrm{KD} /$ silabus dan pembuatan materi maupun pelatihan lain yang dapat mereka ikuti. Dari pelatihan tersebut besar harapannya bisa membantu meningkatkan kinerja guru sehingga pembelajaran yang dilakukan nantinya menjadi lebih baik.

Pendidik dalam menjalankan tugas profesionalisme mereka seminim-minimnya wajib untuk merencanakan pembelajaran dan melaksanakan proses pembelajaran yang telah dirancang dengan kualitas yang baik, serta melakukan proses penilaian/ mengevaluasi hasil pembelajaran yang telah di lakukan. Kinerja guru dapat dipngaruhi oleh beberapa hal seperti kemampuan intelektual mendasar yang dimiliki guru, kepemimpinan kepala sekolah dan faktor sarana prasarana penunjang, Hartana (2013). Sehingga, kinerja guru selalu menjadi sorotan karena menjadi faktor utama dalam meningkatkan kualitas belajar dan kualitas pendidikan. 
Prasarana pendukung yang ada di sekolah tentu juga menjadi alasan yang mempengaruhi kinerja. Sekalipun seorang guru memiliki kemampuan pengusaan ilmu dan teknologi yang tinggi akan tetapi tidak didukung oleh sarana dan prasana, tentu yang ia miliki akan sia-sia. Ibarat akan berperang tetapi tidak memiliki alat perang. Kaitan hal tersebut tentu ada keterkaitan dengan alat pengajaran dan alat-alat peraga pengajaran yang ada di sekolah yang dapat digunakan. Penggunaan itu menjadi bagian upaya meningkatkan kinerja dan kuwalitas pembelajaran yang dilakuin guru sehingga menghilangkan pembelajaran konvensional dalam situasi KBM yang sejak dulu berkesan membosankan dan kurang menarik. Gagari (2010) menambahkan dalam penelitiannya bahwa Kinerja Guru di tiap-tiap undakan pendidikan yaitu SD/MI, SMP/MTS, SMA/MA/SMK dapat dipengaruhi oleh digunakannya atau dimanfaatkan sarpras sekolah yang ada.

Kemampuan guru dalam memanfaatkan alat peraga akan menimbulkan komunikasi langsung antara siswa dengat alat peraga tersebut, dan antara siswa dengan sumber informasi atau guru secara tidak langsung. Akan tetapi faktanya masih banyak ditemui guru yang tidak memanfaatkan alat peraga dalam proses pembelajaran termasuk alat peraga IPS seperti globe, peta dan lain-lain. Padahal sarana alat peraga tersebut disekolah telah tersedia dan hanya menjadi pajangan tanpa dimanfaatkan secara maksimal. Gagari (2010) menambahkan alat peraga mempunyai peranan penting dalam memberikan pengalaman visual kepada siswa sehingga terdorong untuk belajar serta dapat memperjelas konsep abstrak sehingga mempertinggi daya serap belajar.

Berdasarkan hasil pengamatan di sekolah-sekolah SD di Kecamatan Pragaan pada tanggal 26 Desember 2019 seperti di SDN Pakamban Laok, SDN Pakamban Daja, SDN Sentol Laok, SDN Prenduan III, SDN Karduluk II, dan SDN Aeng Panas I ditemukan banyak sekali sekolah yang mempunyai Pemanfaatan alat peraga, media maupun KIT yang dalam hal ini alat peraga IPS. Meskipun Pemanfaatan alat peraga tidak terlalu merata disemua sekolah dan kebanyakan tersedia di kelas atas saja. Alat peraga tersebut masih tersimpan rapi didalam perpustakaan bahkan ada yang sampai kotor tidak terpakai. Banyak juga ditemui pembelajaran IPS yang tidak menggunakan alat bantu (alat peraga) dan hanya menggunakan metode ceramah. Guru hanya duduk didepan menjelaskan materi hanya memanfaatkan sarana buku dan papan tulis tanpa memanfaatkan media atau alat peraga. Hal tersebut seakan guru terkesan hanya bekerja kurang maksimal. Padahal kualitas kinerja guru sangat dipengaruhi oleh tersedianya alat peraga. Kinerja guru yang baik tersebut tentunya dapat berpengaruh terhadap kualitas dan hasil pembelajaran.

Kata kinerja secara bahasa yang berasal dari kata performance yang maknanya "menampilkan atau melaksanakan". Performance berarti "prestasi, pelaksanaan, pencapaian, 
unjuk kerja atau penampilan kerja”. Menurut Mangkunegara dalam Barnawi (2012) menyatakan hasil dari pekerjaan baik kualitas dan kuantitas yang dicapai oleh individu dalam melaksanakan tugas dengan tanggungjawab yang diberi padanya disebut kinerja. Lebih lanjut Rivai dalam Barnawi (2012) menambahkan kinerja adalah tingkatan ketercapaian seseorang secara akumulatif selama jangka waktu tertentu dalam menjalankan tugasnya seperti standart hasil kerjanya/target kerja yang telah disepakati sebelumnya. Sementara menurut Fitria (2018) kinerja merupakan kemampuan seseorang dalam melakukan pekerjaan untuk waktu tertentu dengan indikator kinerja yaitu: kualitas pekerjaan, pekerjaan akurasi, inisiatif, kemampuan, dan komunikasi.

Beban dan tanggungjawab pendidik diatur "Undang-undang Nomor 14 Tahun 2005 Tentang Guru dan Dosen dalam pasal 35". Berat pikulan kerja guru mengkover kegiatan inti, yakni perencanaan, pelaksanakan, mengukur, membina peserta didik dalam proses pembelajaran, serta melakukan beban tambahan lain. Menurut Taylor and Tyler (2012) seorang guru harus mampu menyelesaikan tugasnya dengan baik agar nantinya jika ia menjalani evaluasi tidak mendpatkan score yang rendah atau dengan akat lain kinerjanya buruk. Lebih lanjut dijelaskan oleh Supardi (2013) kinerja guru merupakan kemampuan ia dalam melaksankan tupoksi dia sebagai guru. Guru juga dapat melakukan tugas tambahan selain tugas utama mereka mengajar (Susiani, 2017) Berdasarkan tersebut dapat diintisarikan bahwa Kinerja pendidik/guru adalah pencapaian oleh seorang pendidik/guru secara akumulatif dalam melaksanaakan kewajibannya dalam proses KBM yang diberikan terhadapnya yang ditinjau melalui kegiatan pembuatan perencanaan, pelaksanaan, penilaian dan evaluasi seperti remedial dan pengayaan.

Ketersediaa alat peraga dan tentu penggunaan secara maksimal oleh guru tentu sangat diharapka dalam memaksimalkan proses KBM. Menurut Jonimar (2020) alat peraga adalah segala hal yang dapat menjalaskan konsep dan materi pembelajaran yang awalnya tidak nyata/tidak jelas menajadi riil atau jelas yang membuat rangsangan pikiran, rasa dan focus dan keinginan siswa untuk mengikuti pelajaran. Menurut Imran (2013) tujuan digunakannya alat peraga yakni untuk memperjelas isi atau info materi memberikan pembeda dalam pembelajaran, memperjelas bagian-bagian pengajaran, serta dapat memotivasi siswa dalam mengikuti pembelajaran.

Syarat-syarat alat peraga menurut Wicaksono (2016) yaitu : (1) Rasional, dapat di nalar oleh pikiran (2) Ilmiah, sesuai dengan kemajuan iptek. (3) Ekonomis, sesuai budget keuangan yang dimiliki (4) Praktis, dapat dipakai dalam praktek didepan siswa dengan sifat yang tidak menyusahkan. (5) Fungsional, sesuai tujuan kegunaan, artinya dapat dipakai oleh guru dan siswa dengan baik. 
Berdasarkan perjelasan tersebut diatas, dapat diintisarikan alat peraga adalah segala hal yang dipilih oleh guru/pendidik untuk nanti digunakan dalam pembelajaran dengan tujuan dapat merangsang perhatian dan perasaan sehingga siswa terdorong dengan semangat dan berminat untuk mengikuti proses pembelajaran dan mempermudah guru dan siswa dalam menyajikan dan menyerap materi pelajaran.

Kinerja guru dapat ditingkatkan melalui penggunaan alat peraga. Pendapat tersebut sejalan dengan hasil penelitian Daud (2018) menjelaskan bahwa kegiatan penggunaan alat peraga dengan pembelajaran langsung berhasil meningkatkan kinerja guru. Hal tersebut dapat dibuktikan dari hasil siklus II yang mendapat kategori baik dengan persentase $76 \%$. Selanjutnya oleh Hartana (2013) dalam penelitiannya ia menambahkan bahwa salah satu indicator dalam variable kompetensi pedagogic yang menunjang dan mempengaruhi kinerja guru adalah dapat memanfaatkan alat peraga/media dalam pembelajaran. Kompetensi tersebut berpengaruh sebesar $94,1 \%$.

Peneliti tertarik untuk melakukan penelitian berdasarkan pertimbangan yang ada yang berhubungan dengan alat peraga dan kinerja guru dengan judul penelitian "Pengaruh Pemanfaatan Alat Peraga IPS Terhadap Kinerja Guru Sekolah Dasar di Kecamatan Pragaan Kabupaten Sumenep". Karena peneliti juga memiliki batasan, maka penelitian ini hanya diberi batasan pada (1) peneliti hanya meneliti pemanfaatan alat peraga IPS terhadap kinerja guru di Kecamatan Pragaan Kabupaten Sumenep (2) Mata pelajaran yang diangkat dalam penelitian ini adalah mata pelajaran Ilmu Pengetahuan Sosial.

Rumusan masalah bisa dituliskan sebagai berikut mengacu pada permasalahan: “(1) Bagaimana pengaruh pemanfaatan alat peraga IPS terhadap kinerja guru Sekolah Dasar di Kecamatan Pragaan Kabupaten Sumenep?”. Sedangkan tujuannya untuk mengungkap: “(1) mengetahui bagaimana pengaruh pemanfaatan alat peraga terhadap kinerja guru sekolah dasar di Kecamatan Pragaan Kabupaten Sumenep".

\section{METODE PENELITIAN}

Penelitian ini menggunakan "pendekatan kuantitatif non eksperimen" dimana dalam penelitian ini tidak ada perlakuan terhadap subjek atau responden Riyanto (2012:120). Dengan jenis penelitian "deskriptif kuantitatif", jenis ini data yang diraih pada responden penelitian, kemudian diolah sesuai dengan metodologi penelitian yang ditetapkan. Penelitian deskriptif ini untuk mendapat kejelasan dan ketrangan-keterangan mengenai pemanfaatan alat peraga IPS terhadap kinerja guru di Kec. Pragaan Kab. Sumenep.

Populasi yang ditetapkan dalam penelitian ini yakni seluruh guru SD (guru kelas atas IV, V dan VI) atas dasar pertimbangan bahwa ketersediaan alat peraga IPS hanya tersedia di kelas 
atas dalam dua gugus (Gugus 02 dan 03) yang terdiri dari sepuluh sekolah (SDN Pakamban Laok, SDN Pakamban Daja, SDN Sentol Laok, SDN Rombasan dan SDN Larangan Perreng, SDN Karduluk I, SDN Prenduan III, SDN Karduluk II, SDN Aeng Panas I, SDN Karduluk IV) yang ada di kec. Pragaan kab. Sumenep dengan keseluruhan guru sebanyak 30 guru. Teknik pengambilan sampel pada penelitian ini yakni teknik "sampling jenuh" dikarekan peneliti mampu untuk menjadikan seluruh anggota populasi menjadi sampel. Hal ini banyak dilakukan jika populasi $<30$ orang dalam arti populasi rekatif kecil (Sugiyono, 2014). Dalam penelitian ini, menilik jumlah populasi hanya 30 guru, maka peneliti menjadikan seluruh anggota populasi ditetapkan sebagai sampel penelitian.

Alat yang digunakan untuk mengambil data, yaitu instrumen angket pemanfaatan alat peraga IPS dan kinerja guru sebagai data utama dan lembar observasi beserta dokumentasi sebagai data pendukung dari instrumen angket. Dari kedua Instrumen yang akan digunakan sebelumnya divalidasi oleh ahli materi dan ahli bahasa. Yang selanjutnya diuji cobakan dan dianalisis menggunakan uji validitas dan reliabilitas.

Dari variabel pemanfaatan alat peraga dirumuskan 5 indikator sebagai acuan pembuatan instrumen yang kemudian diturunkan menjadi 20 butir pernyataan valid. Misalnya seperti indikator yang berbunyi "praktis" yang dirumuskan dalam butir pernyataan no. 18 yang berbunyi "Alat peraga yang disediakan guru dapat dijalankan dengan baik". Sedangkan pada variabel kinerja guru dirumuskan 6 indikator yang berfokus pada kemampuan guru dalam menggunakan alat peraga yang kemudian dirumuskan ke dalam 23 butir pernyataan valid. Contoh butir pernyataan misalnya berbunyi "Guru menggunakan media/alat peraga yang sesuai dengan tujuan pembelajaran”. Semua jawaban baik dari validator maupun responden dijamin keaslian dan kejujuran tanpa adanya campur tangan dari orang lain maupun peneliti. Semua itu dapat dibuktikan dari hasil uji validitas, reliabilitas, normalitas dan uji statistik lain yang sesuai dengan prosedur penelitian ilmiah.

Data angket dianalisis menggunakan (uji normalitas, uji homogenitas, uji linieritas, uji regresi linier sederhana, uji signifikansi). Uji normalitas, uji homogenitas dan uji linieritas digunakan sebagai uji prasyarat untuk melakukan uji regresi linier. Uji regresi linier sederhana digunakan untuk memprediksi kinerja guru yang dipengaruhi pemanfaatan alat peraga IPS. Uji signifikansi digunakan untuk menentukan adakah pengaruh yang signifikan pada pemanfaatan alat peraga IPS terhadap kinerja guru. 


\section{HASIL DAN PEMBAHASAN}

\section{Hasil Penelitian}

Deskripsi angket pemanfaatan alat perga IPS dan kinerja guru bertujuan untuk mengetahui bagian dari setiap jawaban yang ditampakkan oleh responden (siswa). Analisis deskriptif akan dijabarkan pada setiap butir pernyataan baik dari angket pemanfaatan alat peraga IPS maupun kinerja guru.

Uji prasyarat meliputi uji normalitas, uji homogenitas, uji linieritas dan uji regresi linier sederhana. Data yang dipakai dalam uji normalitas adalah data angket pemanfaatan alat peraga IPS dan kinerja guru. Metode yang dipakai dalam uji normalitas penelitian ini yaitu Kolmogorov Smirnov. Dimana kaidah pengujiannya adalah adalah $\mathrm{D}_{\text {hitung }} \leq \mathrm{D}_{\text {tabel}}$, maka data berditribusi normal. Berikut ini merupakan table hasil uji normalitas:

Tabel 1. Hasil Uji Normalitas

\begin{tabular}{ccccc}
\hline Data & D $_{\text {hitung }}$ & D tabel & Keterangan & Kesimpulan \\
\hline Alat Peraga IPS & 0.146 & 0.2212 & Normal & data Angket Pemanfaatan Alat \\
Kinerja Guru & 0.134 & 0.2212 & Normal & $\begin{array}{c}\text { Peraga IPS dan Angket Kinerja Guru } \\
\text { adalah berdistribusi normal }\end{array}$ \\
\hline
\end{tabular}

Uji prasyarat berikutnya adalah uji homogenitas. Kriteria pengujian uji homogenitas "jika $F_{\text {hitung }} \geq F_{\text {tabel, }}$ maka dikatakan tidak homogen". "Jika $F_{\text {hitung }} \leq F_{\text {tabel, }}$ maka dikatakan homogen". Berikut ini hasil Uji Homogenitas disajikan pada Tabel 2.

Tabel 2. Hasil Uji Homogenitas

\begin{tabular}{cccc}
\hline Data & Fhitung & Ftabel & Keterangan \\
\hline Nilai Angket & 1.09 & 1.86 & HOMOGEN \\
\hline
\end{tabular}

Uji prasyarat yang ketiga yakni uji linieritas sebagai syarat uji regresi. Berikut ini hasil Uji Linieritas dipaparkan pada Tabel 3.

Tabel 3. Hasil Uji Linieritas

\begin{tabular}{cccc}
\hline Data & Fhitung & Ftabel & Keterangan \\
\hline Nilai Angket & 10,70 & 4,20 & LINIER \\
\hline
\end{tabular}

Setelah selesai uji prasyarat analisis berikutnya dapat dikerjakan uji hipotesis. Uji hipotesis pada penelitian ini menggunkan uji regresi linier sederhana serta uji signifikansi karena yang dijadikan focus penelitian adalah akan mencari bagaimana pengaruh antara 
"variabel bebas $(\mathrm{X})$ terhadap variabel terikat $(\mathrm{Y})$ ". Dimana judul penelitian ini adalah Pengaruh Pemanfaatan Alat Peraga IPS terhadap Kinerja guru.

Langkah pertama untuk mencari pengaruh adalah melakukan uji regresi. Perhatikan hasil uji regresi dalam table berikut:

Tabel 4. Hasil Uji Regresi Linier Sederhana

\begin{tabular}{cc}
\hline Data & Nilai \\
\hline Konstanta $b$ & 0.505 \\
Konstanta $a$ & 23.23 \\
$X$ & $23.23+0.505 \mathrm{X}$ \\
Y & 51.98 \\
Nilai Korelasi & 49.46 \\
\hline
\end{tabular}

Berdasarkan data table tersebut diketahui bahwa konstanta $\mathrm{a}=23.23$ dan nilai konstanta $\mathrm{b}=0.505$, sehingga model persamaannya adalah $\mathrm{Y}=23,23+0,505 \mathrm{X}$. dari persamaan tersebut, diketahui Y adalah Kinerja Guru, sedangkan X adalah Pemanfaatan Alat Peraga IPS. Jadi, hubungan antara Pemanfaatan Alat Peraga IPS terhadap kinerja guru bersifat positif, artinya terdapat hubungan satu arah antara variabel X dan Y, jika nilai dari variabel X bertambah maka nilai Y akan bertambah besar pula. Hal ini dapat disimpulkan bahwa jika Pemanfaatan alat peraga baik, maka kinerja guru semakin baik.

Setelah mengetahui persamaan regresi, selanjutnya dilakukan uji signifikansi. Uji signifikan atau uji hipotesis bertujuan untuk menguji kevalidan persamaan regresi. Persamaan regresi $Y=23,23+0,505 X$ ditetapkan sebagai pondasi untuk memprediksikan tingkatan nilai kinerja guru yang terpengaru oleh Pemanfaatan alat peraga dengan nolai korelasi sebesar 0.526. Uji signifikasi dilakukan dengan kaidah pengujian "jika -ttabel $\leq$ thitung $\leq$ ttabel, maka Ho diterima jika $t_{\text {hitung }}>t_{\text {tabel }}$ maka Ho ditolak "(Siregar, 2014:383). Berikut ini adalah table hasil uji signifikansi:

Tabel 5. Hasil Uji Signifikansi

\begin{tabular}{cc}
\hline Data & Nilai \\
\hline $\mathrm{r}$ & 0,526 \\
thitung & 3,271 \\
ttabel & 2,048 \\
Keputusan & thitung $>\mathrm{t}_{\text {tabel }}(3,271>2,048)$ artinya Ho ditolak dan Ha diterima. Ada \\
& pengaruh signifikan antara Ketersediaan Alat Peraga IPS terhadap \\
& Kinerja guru Sekolah Dasar di Kecamatan Pragaan Kab. Sumenep \\
\hline
\end{tabular}




\section{Pembahasan}

Penelitian ini mempunyai dua variabel yaitu Pemanfaatan Alat Peraga IPS menjadi faktor bebas dan variabel terikatnya adalah Kinerja guru. Sekolah Dasar yang dijadikan sasaran penelitian adalah gugus 2 dan gugus 3 Kecamatan Pragaan Kabupaten Semenep dimana ada 10 sekolah dasar dan 30 guru sebagai responden atau sampel penelitian. Penelitian ini menggunakan instrumen angket terdiri dari dua angket dalam penelitian ini yaitu angket pemanfaatan alat peraga dan angket kinerja guru semua diisi oleh guru berdasarkan presepsi guru tersebut.

Tujuan penelitian disini untuk menguji pengaruh pemanfaatan alat peraga IPS terhadap kinerja guru sekolah dasar di kec. Pragaan kab. Sumenep. Untuk mengetahui besaran pengaruhnya dari variabel $\mathrm{X}$ terhadap variabel $\mathrm{Y}$, terlebih dahulu data yang diperoleh harus dikonversi ke dalam bentuk data interval karena pada sebelumnya masih berbentuk ordinal. Menurut Siregar (2014:3) menjelaskan bahwa data yang digunakan pada statistik parametrik bersifat interval dan rasio.

Setelah data telah dikonversi dalam bentuk interval, selanjutnya melalui uji normalitas dan linieritasnya sebagai uji prasyarat analysis. Hasil uji normalitas dari dua data angket menunjukkan bahwa nilai signifikansi sebesar 0,101 lebih besar dari 0,05. Hal ini singkron dengan patokan pengujian normalitas berdasarkan nilai probabilitas jika nilai signifikansi > 0,05 maka H0 diterima dan H1 ditolak. Sedangkan patokan pengujian jika membandingkan

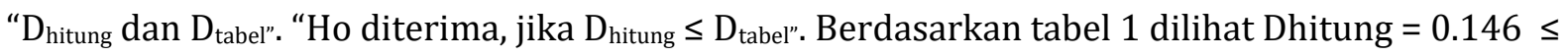
Dtabel $=0.2212$. Jadi dapat disimpulkan bahwa data Angket Pemanfaatan Alat Peraga IPS adalah berdistribusi normal. Sedangkan untuk angket kedua menampakkan bahwa value signifikansi sebesar 0,178 lebih besar dari 0,05. Hal ini singkron dengan patokan pengujian normalitas berdasarkan nilai probabilitas jika nilai signifikansi > 0,05 maka H0 diterima dan H1 ditolak. Sedangkan berdasarkan tabel 4.50 menunjukkan penyebaran data berada disekitar garis diagonal. Sedangnkan kriteria pengujian berdasarkan perbandingan "Dhitung dan Dtabel”. Ho diterima, jika Dhitung $\leq$ Dtabel. Berdasarkan perhitungan dapat dilihat Dhitung $=0.134 \leq$ Dtabel $=0.2212$. Jadi dapat disimpulkan bahwa data Angket Kinerja Guru adalah berdistribusi normal.

Uji prasyarat beriktnya adalah uji homogenitas. Pada uji homogenitas diperoleh nilai Fhitung 1.09 dengan taraf signifikan $(\alpha)=0,05$, hasil uji homogenitas antara Pemanfaatan Alat Peraga IPS dengan Kinerja Guru diperoleh Fhitung = $1.09<$ Ftabel 1.86. Sehingga dapat diambil ketetapan bahwa Ho diterima dan Ha ditolak sehingga "variabel bebas $(\mathrm{X})$ dan variabel terikat (Y) mempunyai varian yang sama (homogen). 
Uji persyaratan yang ketiga adalah uji linieritas sebagai syarat uji regresi. Pada uji linieritas diperoleh nilai Fhitung 10,70 dengan taraf signifikan $(\alpha)=0,05$, hasil uji linieritas antara Pemanfaatan Alat Peraga IPS dengan Kinerja Guru diperoleh Fhitung 10,70 > Ftabel 4,20. Sehingga dapat diambil keputusan bahwa Ho ditolak dan Ha diterima sehingga "variabel bebas (X) dan variabel terikat (Y) berpola linier.

Setelah uji persyaratan analisis telat selesai selanjutnya dapat dilakukan uji hipotesis. Uji hipotesis yang digunkan uji regresi linier sederhana serta uji signifikansi karena pada penelitian ini, yang menjadi fokus penelitian adalah akan mencari sebesrapa besar pengaruhnya "variabel bebas $(\mathrm{X})$ terhadap variabel terikat $(\mathrm{Y})$ ". Dimana judul penelitian ini adalah Pengaruh Pemanfaatan Alat Peraga IPS terhadap Kinerja guru. Suapaya tahu pengaruh satu variable "independent" terhadap satu variabel "dependent" yakni digunakan regresi linier (Siregar, 2014:379). Pengujian dilakukan untuk menjawab hipotesis dari rumusan masalah.

Langkah pertama untuk mencari pengaruh adalah melakukan uji regresi. Berdasarkan data penelitian yang sebelumnya telah diuji diketahui bahwa konstanta a $=23.23$ dan nilai konstanta $b=0.505$, sehingga model persamaannya adalah $Y=23,23+0,505 X$. dari persamaan tersebut, diketahui Y adalah Kinerja Guru, sedangkan X adalah Pemanfaatan Alat Peraga IPS. Jadi, hubungan antara Pemanfaatan Alat Peraga IPS terhadap kinerja guru bersifat positif, artinya terjadi hubungan satu arah antara variable $\mathrm{X}$ dan $\mathrm{Y}$, jika nilai dari variable $\mathrm{X}$ bertambah maka nilai Y akan bertambah besar pula. Hal ini dapat disimpulkan bahwa jika Pemanfaatan alat peraga baik, maka kinerja guru semakin baik.

Setelah mengetahui persamaan regresi, selanjutnya dilakukan uji signifikansi. Uji signifikan atau uji hipotesis bertujuan untuk menguji kevalidan persamaan regresi. Persamaan regresi $Y=23,23+0,505 \mathrm{X}$ digunakan sebagai pondasi untuk memprediksi nilai tingkat kinerja guru yang dipengaruhi oleh Pemanfaatan alat peraga. Uji signifikasi dilakukan dengan kaidah pengujian "jika $-t_{\text {tabel }} \leq t_{\text {hitung }} \leq t_{\text {tabel, }}$, maka $H_{o}$ diterima jika $t_{\text {hitung }}>t_{\text {tabel }}$ maka Ho ditolak" (Siregar, 2014:383).

Berdasarkan pengujian signifikasi menunjukkan thitung $>t_{\text {tabel }}(3,271>2,048)$ artinya "Ho ditolak dan Ha diterima". Jadi dapat diintisarikan ada pengaruh yang signifikan antara Pemanfaatan Alat Peraga IPS terhadap Kinerja Guru Sekolah Dasar Di Kec. Pragaan Kab. Sumenep. Data tersebut diatas diperkuat oleh hasil observasi yang dilakukan peneliti dimana dari jumlah responden sebanyak 30 guru, diperoleh skor total sebesar 1069 persentase keseluruhan sebesar 89\% dengan kategori sangat baik. itu artunya bahwa kondisi Pemanfaatan alat peraga serta kinerja guru dari 30 responden dalam 10 sekolah dalam kondisi sangat baik.

Dari paparan diatas dapat ditarik kesimpulan bahwa Pemanfaatan alat peraga IPS mempunyai pengaruh terhadap kinerja guru. Hal ini selaras dengan pendapat Mulyasa (2010) 
menjelaskan untuk meningkatkan kinerja guru khususnya dalam pembelajaran. Misalnya dilakukan melalui mengikuti diklat, seminar ataupun pelatihan. Seperti diklat, seminar ataupun pelatihan metode pembelajaran, pembuatan media/alat peraga, pemilahan/pengembangan $\mathrm{SK} / \mathrm{KD} /$ silabus dan pembuatan materi maupun pelatihan lain. Dari pelatihan tersebut besar harapannya bisa membantu meningkatkan kinerja guru sehingga pembelajaran yang dilakukan nantinya menjadi lebih baik. Pendapat tersebut sejalan dengan hasil penelitian Daud (2018) menjelaskan bahwa kegiatan penggunaan alat peraga dengan pembelajaran langsung berhasil meningkatkan kinerja guru. Hal tersebut dapat dibuktikan dari hasil siklus II yang mendapat kategori baik dengan persentase 76\%,

Pendidik dalam menjalankan tugas profesionalisme mereka seminim-minimnya wajib untuk merencanakan pembelajaran dan melaksanakan proses pembelajaran yang telah dicancang dengan kualitas yang baik, serta melakukan proses penilaian/ mengevaluasi hasil pembelajaran yang telah di lakukan. Kinerja guru dapat terpengaruh oleh bagian hal seperti kapabilitas intelektual mendasar yang dipunyai guru, kepemimpinan kepala sekolah dan faktor sarana prasarana penunjang, Djatmiko (2006). Sehingga, kinerja guru selalu menjadi sorotan karena mennjadi faktor utama dalam meningkatkan kualitas belajar dan kuwalitas pendidikan.

Sarpras di sekolah tentu juga menjadi factor yang membawa konsekuensi kinerja. Sekalipun seorang guru memiliki kemampuan pengusaan ilmu dan teknologi yang tinggi akan tetapi tidak didukung oleh sarana dan prasana, tentu yang ia miliki akan sia-sia. Ibarat akan berperang tetapi tidak memiliki alat perang. Kaitan hal tersebut tentu erat dengan alat-alat peraga pengajaran yang ada di sekolah yang dapat digunakan. Penggunaan itu sebagai wujud riil dalam meningkatkan kinerja dan kuwalitas pembelajaran yang dilakukan guru sehingga menghilangkan pembelajaran konvensional dalam situasi KBM yang sejak dulu berkesan membosankan dan kurang menarik. Menurut Maharsi (2010) dalam penetiannya mengatakan bahwa kontribusi kemampuan guru dalam memanfaatkan sarana atau alat peraga dalam menunjang kinerja mereka.

Kemampuan guru dalam memanfaatkan alat peraga akan menimbulkan komunikasi langsung antara siswa dengat alat peraga tersebut, dan antara siswa dengan sumber informasi atau guru secara tidak langsung. Menurut Ali (dalam Sundayana, 2013) alat peraga adalah segala hal yang dapat merangsang pemikiran, rasa, fokus dan kemauan siswa sehingga terjadi dorongan proses belajar. Akan tetapi nyatanya masih sering ditemukan guru yang tidak memanfaatkan alat peraga dalam pembelajaran termasuk alat peraga IPS seperti globe, peta dan lain-lain. Padahal sarana alat peraga tersebut disekolah telah tersedia dan hanya menjadi pajangan tanpa dimanfaatkan secara maksimal. Alat peraga mempunyai peranan penting 
dalam memberikan pengalaman visual kepada siswa sehingga terdorong untuk belajar serta dapat memperjelas konsep abstrak sehingga mempertinggi daya serap belajar.

\section{SIMPULAN}

Dari hasil penelitian disimpulkan yaitu pengujian sig. diperoleh nilai $t_{\text {_hitung }}=3,271>$ $\mathrm{t}_{\text {_tabel }}=2,048$, jadi " $\mathrm{H}_{0}$ ditolak dan $\mathrm{H}_{-} \mathrm{a}$ diterima". Sejingga diintisarikan ada pengaruh yang signifikan antara Pemanfaatan Alat Peraga IPS terhadap Kinerja Guru Sekolah Dasar Di Kec. Pragaan Kab. Sumenep. Jika alat peraga dimanfaatkan dengan baik maka kinerja guru akan naik.

Mengacu pada hasil penelitian, saran yang disampaikan diantaranya adalah sebagai berikut: (1) Bagi sekolah hendaknya memperhatikan pemanfaatan sarana dan prasarana penunjang proses pembelajaran terlebih alat peraga IPS karena dapat mempengaruhi kinerja guru. (2) Praktik kinerja guru harus tetap dijaga dan ditingkatkan agar kualitas pendidikan lebih baik. (3) Bagi peneliti selanjutnya, berdasarkan penelitian untuk menunjang kualitas penelitian khususnya yang berkaitan dengan pemanfaatan alat peraga IPS maupun kinerja guru, untuk menggali secara lebih mendalam dapat menyempurnakan hasil penelitian ini dan memperluas variable lain yang belum dilakukan dalam penelitian ini, seperti motivasi guru, profesionalisme guru, keterampilan guru dan pengalaman lapangan guru.

\section{DAFTAR PUSTAKA}

Ah-Sanaky, H. (2011). Media pembelajaran buku pegangan wajib guru dan dosen. Yogyakarta: Safiria Isnia Press.

Amron \& Taufik, I. (2013). Analisis faktor-faktor yang berpengaruh terhadap produktivitas tenaga kerja pada outlet telekomunikasi seluler Kota Makasar. Jurnal Sekolah Tinggi Ilmu Ekonomi Nobel Indonesia, Vol. 5(1), 33-44.

Anas, M. (2013). Alat peraga dan media pembelajaran. Muhammad Anas.

Barnawi, A.M. (2012). Kinerja guru profesional. Jogjakarta: Ar-Ruzz Media.

Bello, S. M. (2012). Impact of ethical leadership on employee job performance. International Journal of Business and Social Science, Vol. 3(11).

Colquitt, J. A., Lepine J. A., \& Wesson M. J. (2015). Organizational behaviour. improving performance and commitment in the workplace, 4th Ed., NewYork: McGraw-Hill Education.

Daud, S. (2018). Upaya meningkatkan kinerja guru melalui penggunaan alat peraga dengan pembelajaran langsung di SDN 007 Rokan IV Koto. Jurnal Pendidikan Rokania, Vol. $3(2), 230-244$. 
Depdiknas. (2005). Pedoman penjamin mutu sekolah dasar/madrasah bertaraf internasional pada jenjang Pendidikan Dasar dan Menengah. Jakarta: Depdiknas.

Fitria, H. (2018). The influence of organizational culture and trust through the teacher performance in the private secondary school in Palembang. International Journal of Scientific \& Technology Research, Vol. 7(7), 82-86.

Gagari, M. Y., et al. (2010). Pengaruh penggunaan dan pemanfaatan sarana dan prasarana sekolah terhadap kinerja guru SD, SMP, SMA dan SMK. Universitas Negeri Hasanuddin.

Hartana, B. (2013). Pengaruh kompetensi pedagogik, kompetensi profesional, dan motivasi kerja terhadap kinerja guru. Jurnal Ilmu Ekonomi dan Sosial, Vol. 2(2), 147 - 162.

Jonimar, J. (2020). Pemanfaatan alat peraga IPA untuk meningkatkan kemampuan guru dan hasil belajar siswa sekolah dasar. ISEJ : Indonesian Science Education Journal, 1(2), 69-84.

Maharsi, D. (2010). Kontribusi kemampuan memanfaatkan media pembelajaran, kecerdasan emosional dalam interaksi sosial dan sikap profesional guru terhadap kinerja guru dalam pembelajaran. Surakarta: Alumni Pascasarjana Unversitas Muhammadiyah Surakarta.

Mulyasa. (2010). Menjadi guru profesional dalam konteks menyukseskan MBS dan KBK. Bandung: Remaja Rosdakarya.

Muntha, B. (2013). Desain pembelajaran. Yogyakarta: Pustaka Insani Madani.

Prastiwi, A. A. (2016). Penggunaan alat peraga kartu bilangan untuk meningkatkan prestasi belajar Matematika kelas IV di SDN 2 Sanggrahan. Basic Education, Vol. 5(10), 922931.

Riduan. (2015). Dasar-dasar statistika. Bandung: Alfabeta

Riyanto, Y. (2012). Metodologi penelitian pendidikan. Surabaya: SIC.

Rohayati, A. (2013). Alat peraga pembelajaran Matematika. Bandung: UPI.

Rostina, S. (2014). Statistika penelitian pendidikan. Bandung: Alfabeta.

Ruseffendi, E. T. (1991). Pengantar kepada membantu guru mengembangkan kompetensinya dalam mengajar Matematika untuk meningkatkan CBSA. Bandung: Tarsito

Rusman. (2010). Model-model pembelajaran mengembangkan profesionalisme guru. Bandung: Mulia Mandiri Pers

Sagala, S. (2011). Manajemen strategik dalam peningkatan mutu pendidikan. Bandung: Alfabeta.

Ibid. (2013). Kemampuan profesional guru dan tenaga kependidikan. Bandung: Alfabeta.

Siregar, S. (2014). Statistik parametik untuk penelitian kuantitatif. Jakarta: PT. Bumi Aksara.

Sugiyono. (2014). Metode penekitian kuantutatif dan kualitatif dan R\&D. Bandung: Alfabeta. 
Sujarweni, W. (2014). Metodologi penelitian lengkap, praktis dan mudah dipahami. Yogyakarta: Pustaka Baru Press.

Sumadinata, N. S. (2010). Metode penelitian pendidikan. Bandung: PT Remaja Rosdakarya.

Sumarno, (2009). Pengaruh kepemimpinan kepala sekolah dan profesionalisme guru terhadap kinerja guru sekolah dasar negeri di Kecamatan Paguyangan Kabupaten Brebes (Tesis, UNNES).

Supardi. (2013). Kinerja guru. Jakarta: PT Raja Grafindo Persada.

Susiani, T. S. (2007). Kinerja calon guru sekolah dasar. Jurnal Inovasi Pendidikan, Vol. 8(2), .

Taylor, E. S., \& Tyler, J.H. (2012). Effect of evaluation on teacher performance. American Economic Review, 102(7): 3628-51.

Hutabarat, W. (2015). The impact of organizational culture, organizational structure, and jobsatisfaction on high school teachers job performance. Jurnal Cakrawala Pendidikan, $34(3), 412-420$.

Wicaksono, A. S. (2016). Pengaruh Model Pembelajaran Langsung Dengan Bantuan Alat Peraga Terhadap Hasil Belajar Matematika Pokok Bahasan Segiempat Pada Peserta Didik Kelas Vii Smpn 1 Panggul Trenggalek (Skripsi, IAIN Tulungagung). 